\title{
The therapeutic value of low-energy laser (LLLT) for enthesitis in children with juvenile spondyloarthropathies
}

\section{Harjacek*, T Kelava and L Lamot}

Address: Children's Hospital Zagreb, Zagreb, Croatia

* Corresponding author

from $15^{\text {th }}$ Paediatric Rheumatology European Society (PreS) Congress

London, UK. 14-17 September 2008

Published: 15 September 2008

Pediatric Rheumatology 2008, 6(Suppl I):P64 doi:I0.I I86/I546-0096-6-SI-P64

This abstract is available from: http://www.ped-rheum.com/content/6/SI/P64

(C) 2008 Harjacek et al; licensee BioMed Central Ltd.

\section{Background}

Children with juvenile spondyloarthropathy (jSpA), classified as enthesitis-related arthritis (ErA), under the ILAR classification, usually experience both arthritis and enthesitis. Therapeutic value of low-energy lasers (LLLT) for enthesitis has not been systematically studied in children with JIA.

\section{Patients and methods}

In this pilot study we report 20 children with jSpA, diagnosed based on both ESSG and ILAR criteria, which we treated, in addition to standard NSAID therapy, with LLLT. We used gallium-aluminium-arsenide (Ga-Al-As) continued laser (Iskra Medical, Slovenia). The usual location of treatment was AC joints, infrapatelar and/or Achilles' tendon insertions. The effects of therapy were determined using the $100 \mathrm{~mm}$ VAS scale for pain reported by patient, before, and 1 month after the therapy. Usual therapy consisted of 10-minute sessions on 10 consecutive days.

\section{Results}

There were 12 girls and 8 boys, medium age 11.4 yrs. (range 7-17). The mean VAS before the therapy was 6.1 (range 4-8) and one month after the therapy was 1.3 (range 0-4). The usual dose used was between $2.5-3 \mathrm{~J} / \mathrm{m}^{3}$ based on localization of enthesitis.

\section{Conclusion}

The biostimulating effect of LLLT is in its anti-inflammatory, analgesic and anti-edematous effect on tissues. It seems that Ga-Al-As laser therapy is a valuable addition to the standard treatment modalities currently used for pain and inflammation treatment of enthesitis in children with jSpA. New patient enrolment and the correlation with six core outcome variables is underway.

\section{References}

I. Brosseau L, Robinson V, Wells G, Debie R, Gam A, Harman K, Morin M, Shea B, Tugwell P: Low level laser therapy (Classes I, II and III) for treating rheumatoid arthritis. Cochrane Database Syst Rev 2005, 4:CD002049. DOI: 10.1002//465 I858.CD002049.pub2.

2. Hawkins $D$, Houreld $N$, Abrahamse $H$ : Low level laser therapy (LLLT) as an effective therapeutic modality for delayed wound healing. Ann N Y Acad Sci 2005, 1056:486-93 [http:// www.walt.nu/dose/index.html]. 